\title{
Effect of plant growth promoting rhizobacteria (PGPR) and IBA treatments on rooting in cuttings of apple (Malus $\times$ domestica Borkh.) clonal rootstock Merton 793
}

\author{
Pramod Verma $^{1^{*}}$, P. S. Chauhan ${ }^{2}$ and J. S. Chandel ${ }^{1}$ \\ Department of Fruit Science, Dr Yashwant Singh Parmar University of Horticulture and Forestry, Nauni, \\ Solan - 173230 (H.P.), INDIA. \\ ${ }^{2}$ College of Horticulture, Dr. Yashwant Singh Parmar University of Horticulture and Forestry, Nauni, \\ Solan - 173230 (H.P.), INDIA. \\ *Corresponding author. E-mail: verma.pramod92@gmail.com \\ Received: June 29, 2016; Revised received: February 20, 2017; Accepted: May 17, 2017
}

\begin{abstract}
The preliminary studies on the effect of different strains of plant growth promoting rhizobacteria (PGPR) alone and in combination with IBA at 1000 ppm on rooting in cuttings of apple clonal rootstock Merton 793 were carried out during 2012-13. The PGPR strains (RG (1) 3 - Bacillus sp.), $\mathrm{B}_{6}-$ Bacillus licheniformis and $\mathrm{R}_{3}(3)-S_{\text {Sirre- }}$ tia $s p$. alone failed to induce rooting response in cuttings of apple clonal rootstock Merton 793 . The results revealed that IBA $2500 \mathrm{ppm}$ recorded the maximum rooting $(65 \%)$, number of primary roots $(5.00)$, length $(28.43 \mathrm{~cm})$ and diameter $(3.25 \mathrm{~mm})$ of primary roots, fresh $(3.67 \mathrm{~g})$ and dry weight $(2.59 \mathrm{~g})$ of roots, length of main shoot $(134.14 \mathrm{~cm})$, diameter of main shoot $(8.18 \mathrm{~mm})$, fresh $(30.40 \mathrm{~g})$ and dry weight $(22.60 \mathrm{~g})$ of shoots in cuttings of Merton 793. However, the PGPR strains RG (1) $)_{3}$ - Bacillus sp., $\mathrm{B}_{6}-$ Bacillus licheniformis and $\mathrm{R}_{3}(3)-$ Sirretia $s p$. in combination with IBA $1000 \mathrm{ppm}$ showed improvement in rooting of cuttings to the extent of 10,15 and 5 per cent rooting, respectively and growth of the rooted plants. IBA at $2500 \mathrm{ppm}$ resulted better rooting and growth of rooted plants. Hence, this treatment is suggested for commercial propagation of apple clonal rootstock Merton 793 through cuttings.
\end{abstract}

Keywords: Apple, IBA, Merton 793, PGPR, Rooting

\section{INTRODUCTION}

Apple is an economically important tree around the world (Karakurt, 2006; Aslantas and Karakurt, 2007). The cultivated apple (Malus $\mathrm{x}$ domesticaBorkh.) is a member of family Rosaceae and sub-family Pomoideae. In India, it is mainly grown in North Western Himalayan region comprising states of Jammu and Kashmir, Himachal Pradesh and Uttrakhand in an area of 312000 ha with a production of 1915000 MT (FAO, 2013). Apple plants are traditionally propagated through grafting and budding on seedling or clonal rootstocks. Though, clonal rootstocks are in use commercially over the world, but seedlings still continues to be the most commonly used rootstock in India, due to sloppy land, rainfed conditions and scarcity of planting material on clonal rootstocks (Negi, 2011).

Among the clonal rootstock, Merton 793, MM 111 and MM 106 are more suitable for agro climatic conditions of North West Himalayas. Merton 793 has been proved to be suitable rootstock for interplanting of old orchards because of its adaptability to a wider range of soil, tolerant to collar rot, replant diseases and resistant to woolly apple aphid (Webster and Wertheim, 2003). Clonal rootstocks of apple are conventionally propa- gated through stooling and hardwood cuttings (Hartrmann et al., 2002). Merton 793 has been reported difficult to root and very less rooting has observed in stool layers (Negi, 2011). Plant growth regulators particularly IBA plays significant role in initiation of rooting in stem cuttings (Hartrmann et al., 2002). There have also been some reports of encouraging rooting with treatment of plant growth promoting substances but its application in rooting of hardwood cuttings of difficult to root rootstock of apple like Merton 793 has not been determined. Keeping in view all these facts, the present study was carried out to assess the effect of different strains of PGPR alone and in combination with IBA on rooting of cuttings in Merton 793 rootstock.

\section{MATERIALS AND METHODS}

The present investigation was undertaken in the Department of Fruit Science, Dr. Y. S. Parmar University of Horticulture and Forestry Nauni, Solan H.P. during 2012-2013 under net house conditions. Hardwood cuttings of $30 \mathrm{~cm}$ in length and 1.00 to $1.25 \mathrm{~cm}$ in diameter were collected from one year old stool shoots in the month of January. These cuttings were subjected to 
quick dip method of IBA treatment, by dipping basal portion of cuttings in $1000 \mathrm{ppm}$ IBA solution for 10 . 15 seconds.After this method cuttings were dipped in $500 \mathrm{ml}$ of plant growth promoting rhizobacteria (PGPR) strains; Strain 1 - (RG (1) $)_{3}$ - Bacillus $s p$.), Strain $2-\left(\mathrm{B}_{6}-\right.$ Bacillus licheniformis $)$ and Strain $3-$ $\left(\mathrm{R}_{3}(3)\right.$ - Sirretia $s p$.) for a period of four hours, under respective treatments. In all, there were seven treatments, $\mathrm{T}_{1}$ :- Strain 1(RG (1) ${ }_{3}$ - Bacillus sp.); $\mathrm{T}_{2}$ :Strain $2\left(\mathrm{~B}_{6}-\right.$ Bacillus licheniformis $) ; \mathrm{T}_{3}$ :- Strain $3\left(\mathrm{R}_{3}\right.$ (3) - Sirretiasp); $\mathrm{T}_{4}-$ Strain $1+$ IBA $1000 \mathrm{ppm} ; \mathrm{T}_{5}-$ Strain 2 + IBA 1000 ppm; $T_{6}-$ Strain 3 + IBA 1000 ppm; $\mathrm{T}_{7}$ :- Control (IBA $2500 \mathrm{ppm}$ ) replicated thrice in a Randomized Block Design

The observations on different rooting parameters such as percentage of rooting was calculated, number of primary roots, length and diameter of primary roots, fresh and dry weight of roots were measured (Hartmann et al., 2002). The length of main shoot was recorded with measuring tape and diameter of main shoot was taken with the help of vernier caliper. Fresh and dry weight of shoot, number of leaves, leaf area and shoot: root ratio was recorded. The data were statistically analyzed and the level of significance for different variables was tested at 5 per cent value of significance with the standard procedure as suggested by Gomez and Gomez (1984).

\section{RESULTS AND DISCUSSION}

As evident from the perusal of results obtained (Table 1), PGPR strains did not induce any rooting response in cuttings of apple clonal rootstock Merton 793. Therefore, the rooting parameters were analyzed statistically for the treatments other than applications of PGPR alone as no roots were recorded in these treat- ments. The maximum rooting success $(65.00 \%)$ was recorded with IBA treatments at $2500 \mathrm{ppm}$. However, the PGPR strains RG $(1)_{3}-$ Bacillus sp., $\mathrm{B}_{6}-$ Bacillus licheniformis and $\mathrm{R}_{3}(3)$ - Sirretia $s p$. in combination with 1000 ppm IBA recorded 10, 15 and 5 per cent rooting respectively indicating the response of IBA application rather than PGPR. In the present study $1000 \mathrm{ppm}$ IBA concentration seems to be insufficient to induce adequate rooting success in Merton 793 cuttings, as better rooting (65\%) success was recorded with higher concentrations of IBA at $2500 \mathrm{ppm}$. These results are in agreement with the findings of Falasca $e t$ al. (2000), who reported that the rooting of bacteria inoculated cuttings can be further accelerated by exogenous IBA application in micro-cuttings of a recalcitrant walnut. Pandey and Pathak (1981) also reported that the best rooting in stem cuttings of apple was recorded with 2500 ppm IBA. Erturk et al. (2010) also reported highest rooting percentage observed in 4000 ppm IBA (65.00\%), followed by 2000 ppm IBA (57.50\%) and equally $47.50 \%$ in Bacillus RC03 and Bacillus simplex RC19, respectively and lowest rooting percentage $(12.50 \%)$ in control in kiwi fruit stem cuttings.

The result pertaining to primary roots per cutting was similar to rooting percentage (Table 2). The maximum number of primary roots (5.00) was recorded in $\mathrm{T}_{7}$. However, $\mathrm{T}_{4}, \mathrm{~T}_{5}$ and $\mathrm{T}_{6}$ recorded $1.90,2.50$ and 1.14 primary roots per cuttings, respectively. The perusal of data in Table 2 reveals that the maximum length and diameter of primary roots was observed in $\mathrm{T}_{7}$, recording $28.43 \mathrm{~cm}$ and $3.25 \mathrm{~mm}$, respectively. However, $\mathrm{T}_{5}$ recorded second highest root length of $9.42 \mathrm{~cm}$. The present observation are in general agreement with Bassil et al. (1991); Benavides and Radice (1998) and

Table 1. Effect of Plant growth promoting rhizobacteria (PGPR) and IBA treatments on rooting of cuttings of apple clonal rootstock Merton 793.

\begin{tabular}{lll}
\hline Treatment & PGPR and IBA & Percentage of rooted cuttings \\
\hline $\mathrm{T}_{1}$ & Strain 1(RG $(1)_{3}-$ Bacillus $\left.s p\right)$ & $0.00(0.00)$ \\
$\mathrm{T}_{2}$ & Strain 2 $\left(\mathrm{B}_{6}-\right.$ Bacillus licheniformis $)$ & $0.00(0.00)$ \\
$\mathrm{T}_{3}$ & Strain 3 $\left(\mathrm{R}_{3}(3)-\right.$ Sirretia sp) & $0.00(0.00)$ \\
$\mathrm{T}_{4}$ & Strain 1 + IBA $1000 \mathrm{ppm}$ & $10.00(18.04)$ \\
$\mathrm{T}_{5}$ & Strain 2 + IBA 1000 ppm & $15.00(22.59)$ \\
$\mathrm{T}_{6}$ & Strain 3 + IBA 1000 ppm & $5.00(12.92)$ \\
$\mathrm{T}_{7}$ & IBA 2500 ppm - Control & $65.00(53.74)$ \\
$\mathrm{CD}_{(0.05)}$ & & 4.63 \\
\hline
\end{tabular}

* Data in parenthesis are angularly transformed values

Table 2. Effect of Plant growth promoting rhizobacteria (PGPR) and IBA treatments on number of primary roots per cuttings, length and diameter of primary roots, fresh and dry weight of roots of cuttings of apple clonal rootstock Merton 793.

\begin{tabular}{lllllr}
\hline $\begin{array}{l}\text { Treat- } \\
\text { ment }\end{array}$ & PGPR and IBA & \multicolumn{2}{c}{$\begin{array}{l}\text { Number of primaryLength of prima-Diameter of prima-Fresh } \\
\text { roots/ cutting }\end{array}$} & $\begin{array}{c}\text { weightDry } \\
\text { ry roots (cm) }\end{array}$ & $\begin{array}{c}\text { weight } \\
\text { ry roots (mm) }\end{array}$ \\
\hline $\mathrm{T}_{4}$ & Strain 1 + IBA 1000 ppm & 1.90 & 7.65 & 0.95 & 2.22 \\
$\mathrm{~T}_{5}$ & Strain 2 + IBA 1000 ppm & 2.50 & 9.42 & 0.86 & 2.42 \\
$\mathrm{~T}_{6}$ & Strain 3 + IBA 1000 ppm & 1.14 & 6.12 & 0.53 & 1.22 \\
$\mathrm{~T}_{7}$ & IBA 2500 ppm - Control & 5.00 & 28.43 & 3.25 & 0.85 \\
$\mathrm{CD}_{(0.05)}$ & & 0.95 & 2.25 & 0.17 & 0.50 \\
\hline
\end{tabular}


Table 3. Effect of Plant growth promoting rhizobacteria (PGPR) and IBA treatments on length, diameter, fresh and dry weight of shoot of cuttings of apple clonal rootstock Merton 793.

\begin{tabular}{llcccc}
\hline Treatment & PGPR and IBA & $\begin{array}{c}\text { Length of main } \\
\text { shoot }(\mathbf{c m})\end{array}$ & $\begin{array}{c}\text { Diameter of main shoot } \\
(\mathbf{m m})\end{array}$ & $\begin{array}{c}\text { Fresh weight of } \\
\text { shoot (g) }\end{array}$ & $\begin{array}{c}\text { Dry weight of } \\
\text { shoot (g) }\end{array}$ \\
\hline $\mathrm{T}_{4}$ & Strain 1 + IBA 1000 ppm & 74.48 & 5.26 & 18.28 & 9.72 \\
$\mathrm{~T}_{5}$ & Strain 2 + IBA 1000 ppm & 79.42 & 5.28 & 20.05 & 10.22 \\
$\mathrm{~T}_{6}$ & Strain 3 + IBA 1000 ppm & 68.62 & 5.12 & 16.32 & 8.15 \\
$\mathrm{~T}_{7}$ & IBA 2500 ppm - Control & 134.14 & 8.18 & 30.40 & 22.60 \\
$\mathrm{CD}_{(0.05)}$ & & 6.88 & 0.72 & 2.51 & 1.95 \\
\hline
\end{tabular}

Table 4. Effect of Plant growth promoting rhizobacteria(PGPR) and IBA treatments on number of leaves, leaf area and shoot: root ratio of cuttings of apple clonal rootstock Merton 793.

\begin{tabular}{llccc}
\hline Treatment & PGPR and IBA & Number of leaves & Leaf area $\left.\mathbf{( c m}^{2}\right)$ & Shoot: root ratio \\
\hline $\mathrm{T}_{4}$ & Strain 1 + IBA 1000 ppm & 44.67 & 20.55 & 8.58 \\
$\mathrm{~T}_{5}$ & Strain 2 + IBA 1000 ppm & 40.00 & 17.72 & 8.31 \\
$\mathrm{~T}_{6}$ & Strain 3 + IBA 1000 ppm & 30.33 & 15.82 & 13.59 \\
$\mathrm{~T}_{7}$ & IBA 2500 ppm - Control & 78.00 & 29.84 & 8.30 \\
$\mathrm{CD}_{(0.05)}$ & & 11.35 & 3.42 & 2.01 \\
\hline
\end{tabular}

Ercisli et al. (2000), showing that IBA + bacteria combined treatments have greater capacity for enhancing rooting, root number and root length of sour cherry cuttings. Whereas, PGPR strains (RG $(1)_{3}-$ Bacillus sp.) along with IBA 1000 ppm also recorded second highest primary root diameter $0.95 \mathrm{~mm}$. Karakurt et al. (2009) also reported that double and triple combination of IBA, bacteria and carbohydrates are more effective in increasing rooting capacity and more quality rooting when compared to carbohydrate, IBA, bacteria and control alone in apple clonal rootstock Merton 793. The maximum fresh and dry weight of roots was recorded in treatment $\mathrm{T}_{7}$ (IBA $2500 \mathrm{ppm}$ ) recording 3.67 $\mathrm{g}$ and $2.59 \mathrm{~g}$, respectively (Table 2). However $\mathrm{T}_{5}$ (Strain $2+$ IBA $1000 \mathrm{ppm}$ ) recorded second highest root fresh weight of $2.42 \mathrm{~g}$ and $\mathrm{T}_{4}$ (Strain $1+1000$ $\mathrm{ppm}$ ) recorded second highest root dry weight of 1.02 $\mathrm{g}$ (Table 2). These observations are in agreement with the findings of Orhan et al. (2006) who reported that seed treatment with IBA, radial cut off, bacteria alone or in combination with radial cut off significantly increased the number of lateral roots, fresh and dry weight of roots in Texas and Nonpareil cultivars of almond. The highest number of lateral roots was in Agrobacterium rubi A18 treatment (8.89) of 'Texas' and A16 treatment (9.60) of 'Nonpareil'. Radicle cut off + OSU-142 treatment of 'Texas' recording fresh weight of $9.89 \mathrm{~g}$ and dry weight of $5.56 \mathrm{~g}$ were found best and in case of 'Nonpareil' Agrobacteriumrubi A 16 were found best in case of fresh and dry weight of roots recording $7.13 \mathrm{~g}$ and $4.39 \mathrm{~g}$, respectively. Erturk et al. (2010) also observed best root dry weight (22.33 $\mathrm{mg}$ ) in the $4000 \mathrm{ppm}$ IBA treatment, as compared to control recording dry weight of $2.56 \mathrm{mg}$ in kiwi fruit stem cuttings.

The results obtained in the present investigation (Table 3 ) revealed that the maximum length of main shoot $(134.14 \mathrm{~cm})$ and diameter of main shoot $(8.18 \mathrm{~mm})$ was recorded in treatment $\mathrm{T}_{7}$ (IBA $\left.2500 \mathrm{ppm}\right)$ followed by $\mathrm{T}_{5}$ (Strain $2+$ IBA $1000 \mathrm{ppm}$ ) recording length of $79.42 \mathrm{~cm}$ and diameter of $5.28 \mathrm{~mm}$ of main shoot of apple rootstock cuttings. These results are in agreement with the findings of Ramesh Chand (1999), who recorded highest average linear growth (132.10 $\mathrm{cm})$ in $\mathrm{M} 7$ clonal rootstock of apple treated with IBA at $2500 \mathrm{ppm}$. Karakurt and Aslantas, (2010) also reported that the application of PGPR (Agrobacterium rubi A18) increased the annual shoot length and diameter was increased, although Burkholderia gladioli OSU-7 application suppressed annual shoot length in apple. As evident from the perusal of results obtained (Table 3) in present studies indicates that the maximum fresh weight of shoots $(30.40 \mathrm{~g})$ and dry weight of shoots $(22.60 \mathrm{~g})$ was recorded in treatment $\mathrm{T}_{7}$ (IBA $2500 \mathrm{ppm}$ ) followed by $\mathrm{T}_{5}$ (Strain $2+$ IBA $1000 \mathrm{ppm}$ ) recording fresh weight and dry weight of shoots 20.05 and $10.22 \mathrm{~g}$, respectively. Similar observation was also made by Hwang, (1987) with auxin treatments who recorded highest fresh weight of shoots in semihardwood cuttings of peach taken in late August or early September when treated with IBA 3500 ppm + NAA 1500 ppm.

The data in Table 4 indicates that the treatment $T_{7}$ (IBA $2500 \mathrm{ppm}$ ) produced maximum number of leaves/cutting (78) and leaf area of $29.84 \mathrm{~cm}^{2}$. PGPR strains alone again in this parameter did not record any leaves. However, $\mathrm{T}_{4}$ (Strain $1+$ IBA $1000 \mathrm{ppm}$ ) recorded highest number of leaves (44.67) and leaf area $\left(20.55 \mathrm{~cm}^{2}\right)$, as compare to other PGPR and IBA combinations. Karakurt and Aslantas (2010) also reported that the application of PGPR (Agrobacterium rubiA18, Bacillus subtilis, OSU-142, Burkholderia gladioli OSU-7 and Pseudomonas putida BA-8) increased the leaf number and leaf area in apple. The maximum shoot: root ratio (13.59) was recorded in treatment $T_{6}$ (Strain 3 + IBA $1000 \mathrm{ppm}$ ). However, the minimum shoot: root ratio (8.30) was recorded in $\mathrm{T}_{7}$ (IBA 2500 ppm). Murthy et al. (2010) reported that exogenous application of auxin at different concentrations seems to activate sugar metabolism for release of energy and 
protein which are necessary for cell division and differentiation during adventitious root primordial initiation or development in the rooting zone of shoot cuttings of vanilla.

\section{Conclusion}

The result obtained reveals that the PGPR strains RG $(1)_{3}-$ Bacillus sp., $\mathrm{B}_{6}-$ Bacillus licheniformis and $\mathrm{R}_{3}$ (3) - Sirretia $s p$. when applied alone in cuttings of apple clonal rootstock Merton 793 did not encourage rooting but their combination with IBA $1000 \mathrm{ppm}$ induces some rooting to the extent of 10,15 and 5 per cent, respectively. Although, the highest rooting percentage of 65 per cent, other root parameters and growth of rooted plants was recorded with $2500 \mathrm{ppm}$ IBA, hence this treatment can be adopted by farmers for mass multiplication of apple clonal rootstock Merton 793 through cuttings.

\section{REFERENCES}

Aslantas, R. and Karakurt, H. (2007). The changes in vegetative growth, pomological characteristics and chemical contents of some apple cultivars growing in two different altitude sea levels. Turkish with English Abstract. Turkish V. National Horticulture Congress, 7: 842-846

Bassil, N. V., Proebsting, W. M., Moore, L. W. and Lightfoot, D. A. (1991). Propagation of hazelnut stem cuttings using Agrobacterium rhizogenes. Hort. Science, 26(8): 1058-1060

Benavides, M. P. and Radice, S. (1998). Root induction in Simmondsiachinensis (Link) Schneid. Using Agrobacterium rhizogenes. Biocell, 22(2): 109-114

Ercisli, S. Esitken, A. and Sahin, F. (2000). The effect of IBA and bacteria (Agrobacterium rubi) on the rooting of cutting of sour cherry cv. Kutahya. Bahce, 29(1-2): $75-80$

Erturk, Y., Ercisli, S. Haznedar, A. and Cakmakci, R. (2010). Effects of plant growth promoting rhizobacteria (PGPR) on rooting and root growth of kiwifruit (Actinidiadeliciosa) stem cuttings. Biological Research, 43: $91-98$

Falasca, G. Reverberi, M. Lauri, P. Caboni, E. Stradis, A. D. and Altamura, M. M. (2000). How Agrobacterium rhizogenes triggers de novo root formation in a recalcitrant woody plant: An integerated histological, ultra structural and molecular analysis. New Phytologist, 145(1):77-93
FAO (2013). Major food and agricultural commodities and producers - countries by commodities. Retrieved from www.faostat.fao.org.

Gomez, K. A. and Gomez, A. A. (1984). In: Statistical Procedure for Agricultural Research $2^{\text {nd }}$ ed. New York: Willey Interscience, 304-309 Pp.

Hartmann, H. T. Kester, D. E. Davies, F. T. and Geneva, R. L. (2002). Plant propagation: principles and practices, $7^{\text {th }}$ Edition. 1: 410

Hwang, K. S. (1987). Studies on factors affecting the rooting of peach cuttings. Korean Journal of Horticultural Science, 44:303-310

Karakurt, H. and Aslantas, R. (2010). Effects of some plant growth promoting rhizobacteria (PGPR) strains on plant growth and leaf nutrient content of apple. Journal of Fruitand Ornamental Plant Research, 18(1): 101-110

Karakurt, H., Aslantas, R., Ozkan, G. and Guleryuz, M. (2009). Effects of indole-3-butyric acid (IBA), plant growth promoting rhizobacteria (PGPR) and carbohydrates on rooting of hardwood cuttings of MM106 apple rootstock. African Journal of Agricultural Research, 4 (2): $60-64$

Karakurt, H. (2006). Determination of effects of some bacteria strains on fruit setting, fruit properties and plant growth on apple. M.Sc. Thesis Graduate School of Natural and Applied Sciences, Ataturk University.

Murthy, G. Umesha, K. Smitha, G. R. and Krishnamanohar, R. (2010). Effect of growth regulators and bio- inoculants on rooting and growth of vanilla stem cuttings. Indian Journal of Horticulture, 67(1): 90-93

Negi, A. (2011). Studies on the multiplication of apple clonal rootstocks through cuttings. M. Sc. Thesis Dr. Yashwant Singh Parmar University of Horticulture and Forestry Nauni, Solan Himachal Pradesh, INDIA.

Orhan, E. Ercisli, S. Esitken, A. and Sohin, F. (2006). Lateral root induction by bacteria, radical cut off and IBA treatments of almond cvs. Texas and Nonpareil Seedlings. SodininkysteIrDarzininkyste, 25(3): 71-76

Pandey, D. and Pathak, R. K. (1981). Biochemical basis of rooting potentiality in apple hardwood cuttings and rooting cofactors and inhibitors. Indian Journal of Hortculture, 38(3, 4): 171-177

Ramesh Chand. (1999). Clonal propagation of some Malling and Malling Merton apple rootstocks through stool layering. MSc. Thesis. Department of Fruit science. Dr. Y S Parmar University of Horticulture and Forestry, Nauni, Solan-173230 (HP), India. 